\title{
Feasibility study of photovoltaic water pump for rice paddy irrigation
}

\author{
Ri Munarto ${ }^{1 \mathrm{a}}$, Arif Faishal $^{2}$ \\ ${ }^{11,2}$ Department of Electrical Engineering, Universitas of Sultan Ageng Tirtayasa, Cilegon- Banten
}

\begin{abstract}
Diesel pumps are commonly used for irrigation purposes of paddy fields at locations far from the grid. Diesel pumps have low reliability because they require high maintenance costs. The use of photovoltaic is a valuable option because the selection decision is not only based on direct biya modal but also includes environmental costs. These solutions reduce the impact of global warming, mitigate negative effects on air quality and contribute to sustainable economic development. Daily sun conditions in Indonesia are average in the horizontal plane within the range of $5-7 \mathrm{kWh} / \mathrm{m}^{2} /$ day and the average daily sun shines within the 7-9 hour. The availability of solar radiation is quite abundant and due to the high cost of grid connections, the pumping of irrigated rice paddy water is beneficial to the water needs for remote communities in Indonesia. It is known from some literature that the photovoltaic irrigation pump system is technically and economically feasible for very small systems in hectares orders. Technical and economic feasibility is determined as a function of the plant and geographical location, including climatic factors, soil quality, ground water depth and recharge rate. The objective of the research is to design a system of pumping irrigation of paddy field of photovolatics to replace previous diesel pumps that meet the criteria of feasibility standard. From simulation using PVSYST 5.0 software, it is known need of solar panel as many as 5 series module and 2 parallel module which fulfill the required eligibility criteria.
\end{abstract}

\section{Introduction}

Technical feasibility is determined as a function of plant type and geographical location which includes climate factor, soil quality, ground water depth and recharge rate of water. The maximum daily volumetric flow rate required for crop irrigation is determined from the maximum evatranspiration rate of the plant during its growing season [1]. Maximum evapotranspiration rate is a function of plant type, soil conditions and climatic conditions. The maximum daily flow rate required is used to determine the required pumping power. The solar panel areas needed to provide the required power use a monthly average solar insolation and are compared with the total field area [2]. Solar insolation represents the amount of solar radiation received over a single day on the Earth's surface measured in $\mathrm{kWh} / \mathrm{m}^{2} /$ day. On cloudy days, light is scattered over sunny days, so the amount of light

\footnotetext{
${ }^{\text {a }}$ Corresponding author: rim.moenarto@gmail.com
} 
reaches the surface is reduced. Areas with the same latitude that have a cloudy day, will have a very low insolation rate\{1]. Solar photovoltaic water pumping has been recognized as suitable for grid-isolation rural locations in poor countries where there are hight levels of solar radiation. The power output for the photovolatic array depend upon insolator and availability of sun per daya i.e sunshine hours available on particular location per day. The insolation varies from one location to another, mounth to mounth because of seasional and climate chnge. [3]. Photovoltaic irrigation systems are technically feasible if there is enough land available to install solar panels. Technical feasibility is determined from the maximum power required for irrigation, which depends on the type of plant and geographic location.

The high cost of photovoltaic irrigation requires prior to further study, it is necessary to measure the dimensions of the photovoltaic installation as accurately as possible. The method used consists of three stages: (1) Determining irrigation needs according to soil type characteristics and climate, (2) Hydraulic analysis of pumping system made according to the aquifer depth and altitude required to stabilize pressure on the water distribution network, (3) After determines the peak photovoltaic power required for irrigation by taking into account the overall yield of the photovoltaic pump irrigation system. Use of photovoltaic irrigation pumps to increase socially significant plant output by optimizing the use of water from solar energy sources and at the same time preserving the environment. The main objective of providing a simple procedure for estimating the design requirements of a photovoltaic system to provide photographic power is based on a separate photovoltaic pumping system from the water requirements of the plant. In order for connections between irrigation systems and pumping equipment with solar energy to be energy efficient and economical, some things must be taken into account: (1) efficient use should be made to water resources, ie only the amount of water needed for crops to be raised, taking into account the rainfall prevention capacity of the soil during the rainy season, (2) the amount of water should be raised to the minimum height above the soil required to stabilize the pressure on the irrigation head and (3) the most efficient irrigation system for a particular plant that should be used.

These guidelines, written in the style of a submission to MATEC Web of Conferences, explain how to prepare your paper using Microsoft Word. Please submit sources files directly to the conference organizers. If they chose to provide print-ready PDF documents to the publisher, you have to submit high-resolution PDF file with all fonts embedded (see PDF guidelines) instead of the sources files. In this case, please remember that no final corrections will be made by the publisher.

\section{Methodology}

\subsection{Rainfall data}

Rainfall data that have been obtained from Meteorology and Geophysics Agency Serang is the average rainfall data period of two weekly or half monthly. Then do the sorting of data from the largest value to the smallest value. From the literature, then can be obtained the amount of rainfall $80 \%$ of R80 is from the fourth order data. The amount of effective rainfall for rice plants is $70 \%$ of the rainfall of $80 \% \mathrm{R} 80$, to obtain effective rainfall for rice crops in January the first period of 158.83 , or the January rice re $10.58 \mathrm{~mm} /$ day, and $70 \%$ of R80 paddy in January second period was 65,87 or re of January second period that is 4,39 $\mathrm{mm} /$ day. 


\subsection{Need of water}

\subsubsection{The total need of water in the field}

The total need of water in the field is the water required from the start of the land preparation, the land preparation, so that it is ready for planting, until the harvest time. In other words, water is needed from the beginning until the completion of planting. The total water requirement in the rice field can be calculated by the formula:

$$
G F R=E t c+P+W L R
$$

$G F R$ : the need for total water in the rice field ( $\mathrm{mm} /$ day) or (Liter/day hectare)

Etc : Evapotranspirasi costant ( $\mathrm{mm} /$ day)

$W L R$ : Water Layer Replacement ( $\mathrm{mm} /$ day)

$P \quad$ : Perlocation.

\subsubsection{Needs water retrieval (DR)}

$$
D R=\frac{N F R}{8.64 * e f}
$$

$D R$ : the need for water in the field (Liter/sec/hectare)

$N F R$ : Net water need in paddy fields ( $\mathrm{mm} /$ day)

ef : Efficieny of irrigation (65\%)

\subsubsection{The need for clean water in the fields (NFR)}

The need for clean water in the fields is the need for total water in the fields reduced by effective rainfall.

$$
N F R=E t c+P+W L R-\operatorname{Re}
$$

Re : Effectice rainfall (mm/day)

After the net water needs are known, the water requirement for irrigation of rice crops can be obtained, so that the following values are obtained:

IR in the first January period $-2.69 \mathrm{~mm} /$ day

DR in January the first period -0.311 liter/second/ hectare

IR in January second period $6.83 \mathrm{~mm} /$ day

DR in January second period 0.79 liter/second/hectare,

and then the calculation can be continued covering the next months in a year. Taking water through a photovoltaic pump to irrigate a rice plant area of $2101.44 \mathrm{~m} 2$ or 0.2101 hectares, then the monthly water requirement for flowing rice cultivation can be shown in Table 3.1. From table 3.1, it can be seen that the maximum water requirement for rice cultivation process is August at $31.74 \mathrm{~m}^{3} /$ day.

\subsection{Batterey}

The required battery capacity can be calculated at 77.90Ah / day. With a voltage rating of $48 \mathrm{~V}$, it takes 4 batteries that strung the series. Design calcultation for solar pumping system[4]: 
- Head of water level from the pump to the vertical lift (6.42 m)

- Pipe length 34,42 m

When installed a water storage tank with a height of $2.82 \mathrm{~m}$ and a diameter of $4.37 \mathrm{~m}$, then can be calculated the following :

- Flow rate of 190 liters/minute

- Friction loss $1.37 \mathrm{~m}$ (2 inch diameter pipe)

- Total Dynamic Head 7.84 m

- Hydraulic pump energy $0.67740 \mathrm{kWh} /$ day

- Hydraulic power $135.48 \mathrm{~W}$ (assuming 5 hours of solar irradiance)

- Mechanical power, $\mathrm{P}_{\mathrm{m}}=301.06 \mathrm{~W}$

- Power, $\mathrm{P}_{\mathrm{e}}=327.24 \mathrm{~W}$

- System efficiency $41.09 \%$

- Duration of operation of pumps 2,983 hours/day (rounded 3 hours/day) .

\subsection{The size of photovoltaic array}

The size of photovoltaic array is determined based on the required electrical power, so that the photovoltaic area, PV area $=2,875 \mathrm{~m}^{2}$. From the photovoltaic area, Peak Solar Insolation $\left(100 \mathrm{~W} / \mathrm{m}^{2}\right)$ and solar panel efficiency, obtained power generated by solar panels, $\mathrm{P}_{\text {watt peak }}=421.18$ Watt peak. For a $72 \mathrm{~V}$ voltage rating, it takes a series of solar panel series on one string of 4.11 and rounded to 5 . The number of string strings is 1.02 (rounded 2), $\mathrm{V}_{\text {mpp array }}=87.5 \mathrm{~V}, \mathrm{I}_{\text {mpp array }} 11.42 \mathrm{~A}$.

\subsection{Solar panels}

The laying of the elevation angle of the solar panel is determined by the location of the laying area of the solar panel. Geographical location of Banjarsari village can be seen in Table 1. Due to the geographical position of the Banjarsari village area in the southern hemisphere, the solar altitude reference is based on the north pole of the earth and the tilt angle is oriented towards the North Latitude (LU).

Table 1. Geographical location of banjarsari village

\begin{tabular}{|l|c|c|c|}
\hline & Winter solstice & Equinox & Summer solstice \\
\hline Declination & $+23,5^{\circ}$ & 0 & $-23,5^{\circ}$ \\
\hline Solar Altitude & $107,43^{\circ}$ & $83,93^{\circ}$ & $60,43^{\circ}$ \\
\hline Tilt angle & $-17,43^{\circ} \mathrm{LU}$ & $6,07^{\circ} \mathrm{LU}$ & $29,57^{\circ} \mathrm{LU}$ \\
\hline
\end{tabular}

The determination of the elevation angle of the solar panel is determined based on the average tilt angle value during winter solstice and summer solstice, then the angle of elevation of Banjarsari is $23^{\circ}$ LU. Determination of fixed tilt angle is recommended at least $15^{\circ}$ [8]. This is because a low tilt angle can make solar panels covered with dust and stagnant water when exposed to rainfall that will result in reduced output energy. The azimuth angle of solar panel used using azimuth angle obtained from research result using solar tracker from case study of Serang area (Hardiansyah, 2012).

\section{Results and discussion}

Table 2 shows the balance and main results of the paddy irrigation pump rice irrigation system. The global horizontal irradiation per year is $1381 \mathrm{kWh} / \mathrm{m}^{2}$. The virtual energy of photovoltaic arrays at Maximum Power Point, $\mathrm{E}_{\text {ArrMPP }}$ is $1139.5 \mathrm{kWh}$. The required energy 
operates an average annual pump of 35.36. The energy required to fill the water tank to the full averaged annual $17.43 \mathrm{kWh}$. The height of the pump head is $7.092 \mathrm{~m}$. The effort required for pumping an annual average of $23.61 \mathrm{~m}^{3} /$ day. While the business is actually used for pumping $23.55 \mathrm{~m}^{3} /$ day. Miss occurs in several months of the year, ie the months of August, September, October and December amounted to $4.109 \mathrm{~m}^{3} /$ day, $2.735 \mathrm{~m}^{3} /$ day, 1.764 $\mathrm{m}^{3} /$ day and $0.445 \mathrm{~m}^{3} /$ day. Average miss $0.865 \mathrm{~m}^{3} /$ day

Table 2. Balance and Main Result

\begin{tabular}{|c|c|c|c|c|c|c|c|c|}
\hline Months & $\begin{array}{c}\text { GlobEff } \\
\left(\mathbf{k W h} / \mathrm{m}^{2}\right)\end{array}$ & $\begin{array}{c}E_{\text {arrMPP }} \\
(\mathrm{kWh})\end{array}$ & $\begin{array}{c}\mathbf{E}_{\text {pumpOp }} \\
(\mathrm{kWh})\end{array}$ & $\begin{array}{l}\mathbf{E}_{\text {tkFull }} \\
(\mathrm{kWh})\end{array}$ & $\begin{array}{c}\mathbf{H}_{\text {pump }} \\
\text { (meter) }\end{array}$ & $\begin{array}{c}W_{\text {pump }} \\
\left(\mathbf{m}^{3 / \text { day }}\right. \\
\text { ) }\end{array}$ & $\begin{array}{c}W_{\text {used }} \\
\left(\mathbf{m}^{3} / \text { day }\right. \\
)\end{array}$ & $\begin{array}{c}W_{\text {miss }} \\
\left(\mathrm{m}^{3} / \text { day }\right. \\
)\end{array}$ \\
\hline January & 145,5 & 120,3 & 29,59 & 50,09 & 7,001 & 16,23 & 14,35 & 0,000 \\
\hline February & 112,4 & 92,6 & 28,39 & 34,25 & 6,970 & 17,00 & 17,29 & 0,000 \\
\hline March & 131,4 & 108,5 & 39,32 & 31,35 & 7,095 & 21,52 & 21,55 & 0,000 \\
\hline April & 114,0 & 93,9 & 44,24 & 16,20 & 7,107 & 25,07 & 25,08 & 0,000 \\
\hline Mei & 109,4 & 90,8 & 46,22 & 10,35 & 7,084 & 25,40 & 25,53 & 0,000 \\
\hline June & 97,8 & 81,1 & 46,34 & 4,22 & 7,115 & 26,58 & 26,47 & 0,000 \\
\hline July & 105,9 & 88,2 & 38,84 & 15,79 & 7,095 & 21,32 & 21,39 & 0,000 \\
\hline August & 92,0 & 75,8 & 46,50 & 1,86 & 7,215 & 25,73 & 26,63 & 4,109 \\
\hline September & 96,4 & 79,5 & 47,96 & 0 & 7,205 & 27,51 & 28,32 & 2,735 \\
\hline October & 143,8 & 117,4 & 54,76 & 21,63 & 7,090 & 30,26 & 27,46 & 1,764 \\
\hline November & 119,2 & 98,5 & 47,35 & 17,43 & 7,092 & 26,81 & 26,73 & 0,000 \\
\hline Desember & 113,6 & 93,0 & 35,56 & 24,42 & 7,065 & 19,52 & 19,45 & 0,445 \\
\hline Years & 1381,4 & 1139,5 & 501,17 & 227,59 & 7,107 & 23,61 & 23,55 & 0,865 \\
\hline
\end{tabular}

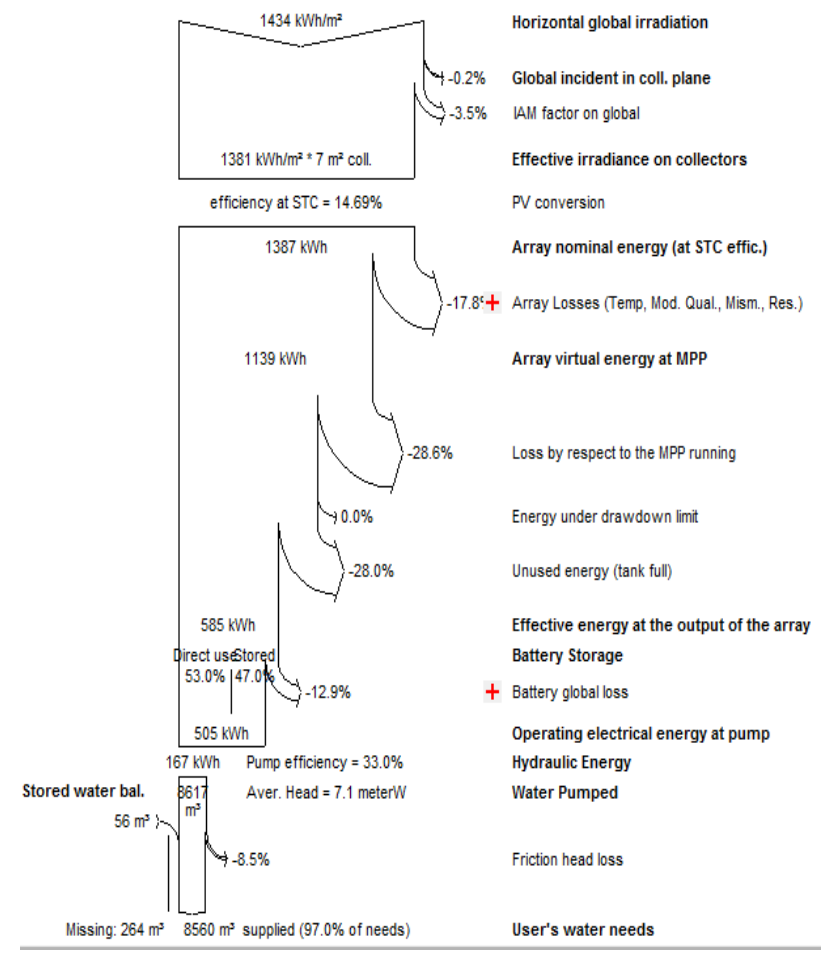

Fig. 1. Overall loss diagram

Figure 1 shows the overall system disadvantage diagram of irrigation pump irrigation system of agricultural land in Banjarsari village. Horizontal global irradiation 1434 
$\mathrm{kWh} / \mathrm{m}^{2}$. Irradiation is effective on the collector field $1381 \mathrm{kWh} / \mathrm{m}^{2}$. The magnitude of irradiation is effectively influenced by two environmental factors, namely the incident global factor of $0.2 \%$ and the Incidence Angel Modifier on global resulting in a decrease in irradiation that actually reaches the $3.5 \%$ photovoltaic cell surface associated with radiation in the normal event. Further photovoltaic cells convert solar energy into electrical energy. After photovoltaic conversion, the nominal array energy is $1387 \mathrm{kWh} / \mathrm{m}^{2}$. Efficiency of photovoltaic arrays $17.8 \%$ in Standard Test Condition. Virtual energy array obtained 1139 $\mathrm{kWh}$. Effective energy at $585 \mathrm{kWh}$ array output. Battery efficiency $12.9 \%$. The electrical energy used operates a $505 \mathrm{kWh}$ pump. Pump efficiency 33\%. Hydraulic energy $167 \mathrm{kWh}$. Water pumped $8617 \mathrm{~m}^{3}$. Friction head loss of $8.5 \%$. Water required user $8560 \mathrm{~m}^{3}$. Water lost $264 \mathrm{~m}^{3}$.

\section{Conclusion}

In this research, the design result of irrigation pumping system of rice field photovoltaic in Banjarsari village, Serang regency with the software used. Maximum solar irradiation at tilt angle $23^{\circ}$ for Banjarsari village is close to the latitude of its location $\left(23^{\circ} 28^{\prime}\right)$ and no shadding effect should be considered. In the irrigation pumping system of paddy fields of photovoltaic rice, the energy used injects pumps is $505 \mathrm{kWh}$ (pump efficiency $33 \%$ ). A Performance Ratio of 0.76 and some power losses can be calculated. Known miss occurs on several months of the year, with the largest miss in August of $4.109 \mathrm{~m}^{3} /$ day.

\section{References}

1. Leah C. Kelley, Eric Gilbersertsin, Anwar Sheikh, Steven D. Espinger, Steven Duboorsky, On the Feasibility of Solar-Power Irrigation, Renewable and Sustainable Energy Review.

2. E. PDNarale, "Study of Solar PV Water Pumping System for Irrigation of Horticulture Crops," Int. J. Eng. Sci. Invent. ISSN (Online, vol. 2, no. 12, pp. $2319-6734$ (2013)

3. Er. P.D. Narale, Dr. N.S. Rathore, Dr. S. Kothari, Study of Solar PV Water Pumping System for Irrigation of HolticultureCrops, International Journal of Engineering Science Invention, ISSN (Online), 2919-6734.

4. Naveen Kumar Lodha, K. Sudhakan, Theoritical Design and Simulation Analysis of PV Based Pumping System for Domestic Application in Bhopal, M.P., India, International Journal of Science and Research, ISSN (Online): 2319-2064.. 